Saudi Journal of Oral and Dental Research

Abbreviated Key Title: Saudi J Oral Dent Res

ISSN 2518-1300 (Print) |ISSN 2518-1297 (Online)

Scholars Middle East Publishers, Dubai, United Arab Emirates

Journal homepage: https://saudijournals.com

\title{
Assessment of Dental Healthcare Services and Workforce in the Jazan Region, Saudi Arabia
}

\author{
Mosa A. Shubayr ${ }^{1}{ }^{2 *}$, Estie Kruger ${ }^{3}$, Marc Tennant ${ }^{3}$ \\ ${ }^{1}$ School of Human Sciences, The University of Western Australia, Nedlands, Australia \\ ${ }^{2}$ Department of Preventive Dental Sciences, College of Dentistry, Jazan University, Jazan, Kingdom of Saudi Arabia \\ ${ }^{3}$ International Research Collaborative, Oral Health and Equity, School of Human Sciences, The University of Western Australia, Nedlands, Australia
}

DOI: $\underline{10.36348 / \text { sjodr.2021.v06i01.017 }}$

| Received: 13.01.2021 | Accepted: 25.01.2021 | Published: 27.01.2021

*Corresponding author: Mosa Ali Shubayr

Abstract

This study focuses on the Jazan region, Kingdom of Saudi Arabia (KSA), To date, there has not been any documented evidence about dental health care in the region. The study aimed to provide an overview of dental healthcare services in Jazan, Saudi Arabia. Mainly secondary data were used in this study. Searches were conducted on MEDLINE, One Search Website, and Google Scholar. Most recent publicly available data were included that describe the current practice. The search was conducted between June 2020 and Jan 2021 for published documents including peer-reviewed manuscripts and published government documents on public oral health system in Jazan. We also obtained unpublished documents form the regional health directorate. There were $103(59.2 \%)$ PHCs and $21(12.1 \%)$ hospitals which had a dental component in Jazan region. Sabya City has the higher number of PHCs compared to other cities. Some cities do not have a dental service provided by PHCs, such as Al Harth and Atwal, which have four and five PHCs respectively but do not have dental clinics. The distribution of providers and services, the low number of dental hygienists and assistants, and the type of facility (PHCs or hospitals) are some of the issues in encountering dental service in the Jazan region. Further primary research focusing on different cities or geographical areas in the Jazan region is needed to validate these findings.

Keywords: Dental healthcare services, oral health and oral health status, dental workforce, Jazan, Saudi Arabia.

Copyright () 2021 The Author(s): This is an open-access article distributed under the terms of the Creative Commons Attribution 4.0 International License (CC BY-NC 4.0) which permits unrestricted use, distribution, and reproduction in any medium for non-commercial use provided the original author and source are credited.

\section{INTRODUCTION}

The Ministry of Health (MOH) in the Kingdom of Saudi Arabia (KSA) funds most of the health care system in the country. The Ministry was established in 1950 [1], and regulates 53\% of all the medical centers in the country, as well as $62 \%$ of the country's hospitals. Other government sectors receive annual budget from the KSA government and provide approximate $9 \%$ of the total health services in KSA [2]. The healthcare system in KSA is a mix of public and private health-care delivery system and $\mathrm{MOH}$ is responsible for managing, planning, implementing, promoting, and evaluating the health services provided. Public healthcare services are provided at all levels [3]. Primary Healthcare Centers (PHC) provide preventative and curative services such as vaccinations, dental care, health education, and environmental health $[4,5]$. Patients are refereed to general hospitals and specialized clinics and hospital to receive advanced and complex treatment. Currently, the MOH 2261 primary healthcare centers (PHC) and 286 hospitals [6]. Despite private sector health clinics and hospitals are owned and operated by individuals and/or by private companies, their duties and staff training are managed by the $\mathrm{MOH}$ [7].

According to the World Health Organization [8], the healthcare system in Saudi Arabia was ranked 26th in the world, ahead of most other Gulf Countries. It also ranked higher than some developed countries, such as Canada (30th), Australia (32nd), and the USA $(37 \text { th })^{3}$. Even though the KSA international high ranking in healthcare, the government is keen on improving health services as demonstrated by the huge annual budgetary allocation [9]. The KSA government has given high priority to the development of healthcare services at all levels [10]. One key indicator of the government's commitment is healthcare financing. For example, in 2019, the total MOH budget represented $8.41 \%$ (approximately 93 billion S.R or $\approx 35$ billion 
Mosa A. Shubayr et al; Saudi J Oral Dent Res, Jan, 2021; 6(1): 81-87

Australian dollars) of the total national budget [6] which was higher than that reported about 5 years prior $8.19 \%$ of the total budget (70 billion S.R) [6]. There is a lack of available data of the share of total healthcare expenditure on oral healthcare.

Despite these achievements, there are still enormous challenges in providing better healthcare services to the fast-growing population of the KSA [10]. This continued population growth has led to high health care costs and challenges and difficulty to maintaining health care quality throughout the country. Furthermore, there is a lack of workforce planning since KSA faces a considerable shortage in the number of local healthcare professionals, thus it relies upon foreign health care nationals to provide critical services. This results in workforce instability and a high turnover rate [2]. The quality of health service provision measured though patients surveys has shown a high regional variability of the satisfaction scores. Findings form a survey on patients' satisfaction with Saudi $\mathrm{MoH}$ health services in the third quarter of 2020, revealed that the patients' satisfaction score was $72.75 \%$ where regional satisfaction scores varied between 59.82 and 92.53 [11]. Compared with the other regions in the country, Jazan region scored the lowest patient satisfaction levels. The various components influencing patients' experience with Saudi's $\mathrm{MoH}$ health services has been explored using quantitative methods [12].

The public dental healthcare sector faces similar challenges. Oral healthcare services are offered free of charge for all citizens and residents of the KSA, yet, the majority of those entitled to benefit from the service seems to choose to receive treatment in private dental clinics [3].

Regarding oral health outcomes, it has been reported that the country has experienced a significant increase in dental caries [13-16]. Some studies found that the prevalence of dental caries had increased dramatically from 68 to $96 \%[17,18]$. The high prevalence of dental caries has been reported among all ages, including children, adults, and older individuals $[18,19]$. In the Jazan region, dental caries prevalence is high, and similar to the studies conducted in other cities of Saudi Arabia [20, 21]. In addition to the reasons such as inadequate oral hygiene practices, high consumption of soft drinks, and high sugar consumption more generally, this high prevalence of caries might be due to not being seen by a dentist consistently [22].

By exploring dental health services provided by MOH facilities in the Jazan Region of the KSA, this study will provide relevant information on current services and provide recommendations for the future improvement of public dental healthcare services and workforce. To our knowledge, there have been no published studies describing the current dental care services provided by the $\mathrm{MOH}$ in the Jazan region. This study will fill a gap in the current literature on the oral health system in Jazan, which will also provide important insights into the functioning of the oral health system in the KSA as a whole.

\section{MATERIALS AND METHODS}

A mixed methodological approach was adopted in this study where data were obtained from primary and secondary sources, mainly in the form of document analysis. Additional information was obtained from unpublished documents of the Regional Heath directorate. We conducted a non-systemic search of the literature to provide an overview of the governmental dental healthcare services in Jazan, Saudi Arabia. The review was carried out using the electronic databases of MEDLINE, One Search Website, and Google Scholar.

The key terms used in the literature search were public dental healthcare services and dental workforce, Jazan region, the initial step of the search included the identification of the data related to the main variables included in the study. The second step involved the selection of the resources that met the inclusion criteria, and the third step involved the comprehensive reading of the collected articles. Finally, the last step involved checking the references of the identified articles to identify further studies that were not identified previously in steps one and two.

Published peer-reviewed literature and government documents on oral health or the oral health system in Jazan were analyzed if they met the following criteria: they were related to the oral health system in Jazan, if they assessed dental health services and /or provided information on related factors (demographic information on the population of Jazan, types of $\mathrm{MOH}$ dental clinics), and if they were written in the English language. The analysis included also publicly available documents from the $\mathrm{MOH}$ Statistical Yearbook of the Ministry of Health [6], along with information from the General Authority of Statistics in Saudi Arabia [23-25]. These documents included information on the number and locations of facilities, and the structure of dental services offered. The documents also provided demographic information on oral health providers who work in MOH dental clinics, as well as the number of dental schools and dentists graduating annually.

A data extraction form was developed to collect information on six main categories from each document: Governorate (Mohafadat in Arabic) name, population number, type of health facility (Primary Health Care Centers and hospitals), number of oral providers (dentists, hygienists, and assistants), and the ratio of dentists-population. To present quantitative data, frequency and percentages were chosen as summary measures. Main variables were extracted from the studies, summarized, and presented according to 
Mosa A. Shubayr et al; Saudi J Oral Dent Res, Jan, 2021; 6(1): 81-87

their frequency of occurrence in the studies. Thus, all relevant topics were extracted from the studies.

\section{RESULTS AND DISCUSSION}

There are 152 PHCs and 22 hospitals serving people in Jazan with 103 (59.2\%) PHCs and 21 (12.1\%) hospitals including a dental component. In Sabya City,
(Table-1). 16 out of 21 PHCs had dental clinics, which is the highest number of PHCs compared to other cities in Jazan. Some cities do not have dental services provided by PHCs, such as Al Harth and Atwal, which have four and five PHCs respectively but do not include a dental clinic.

Table-1: Descriptive Statistics of MOH Facilities in Jazan region

\begin{tabular}{|c|c|c|c|c|c|c|c|c|c|c|c|c|c|c|c|}
\hline \multirow[t]{3}{*}{$\#$} & \multirow{3}{*}{$\begin{array}{l}\text { Governo } \\
\text { rate } \\
\text { (Mohafa } \\
\text { dat) }\end{array}$} & \multicolumn{7}{|c|}{ Population } & \multicolumn{2}{|c|}{$\begin{array}{l}\text { Health Facility } \\
\text { Facility with } \\
\text { DC/T }\end{array}$} & \multicolumn{4}{|c|}{$\begin{array}{l}\text { Providers (Dentists) } \\
\text { PHCs / Hospital }\end{array}$} & \multirow{3}{*}{$\begin{array}{l}\text { Dentist } \\
- \\
\text { Populat } \\
\text { ion } \\
\text { Ratio } \\
\end{array}$} \\
\hline & & \multirow{2}{*}{$\begin{array}{l}\text { Total } \\
\text { populat } \\
\text { ion }\end{array}$} & \multicolumn{3}{|l|}{$S$} & \multicolumn{3}{|c|}{ Non- $\mathrm{S}$} & \multirow{2}{*}{ PHCs } & \multirow{2}{*}{$\begin{array}{l}\text { Hospit } \\
\text { als }\end{array}$} & \multirow{2}{*}{$\begin{array}{l}\text { Resi } \\
\text { dent }\end{array}$} & \multirow{2}{*}{$\begin{array}{l}\text { Regis } \\
\text { trar }\end{array}$} & \multirow{2}{*}{$\begin{array}{l}\text { Consul } \\
\operatorname{tant}\end{array}$} & \multirow{2}{*}{$\mathrm{T}(\%)$} & \\
\hline & & & $\mathrm{F}$ & M & $\mathrm{T}$ & $\mathrm{F}$ & $\mathrm{M}$ & $T$ & & & & & & & \\
\hline 1 & Jazan & 134764 & $\begin{array}{l}4296 \\
3 \\
\end{array}$ & $\begin{array}{l}4910 \\
3 \\
\end{array}$ & 92066 & $\begin{array}{l}109 \\
66 \\
\end{array}$ & $\begin{array}{l}3173 \\
2 \\
\end{array}$ & $\begin{array}{l}4269 \\
8 \\
\end{array}$ & $13 / 15$ & $3 / 4$ & $13 / 8$ & $0 / 10$ & $0 / 6$ & $\begin{array}{l}37(17 . \\
7)\end{array}$ & $1: 3,642$ \\
\hline 2 & Sabya & 228375 & $\begin{array}{l}8923 \\
9\end{array}$ & $\begin{array}{l}8648 \\
8\end{array}$ & $\begin{array}{l}17572 \\
7\end{array}$ & $\begin{array}{l}184 \\
01\end{array}$ & $\begin{array}{l}3424 \\
7\end{array}$ & $\begin{array}{l}5264 \\
8\end{array}$ & $16 / 21$ & $1 / 1$ & $17 / 3$ & $0 / 4$ & $0 / 0$ & $\begin{array}{l}24(11 . \\
5)\end{array}$ & $1: 9,515$ \\
\hline 3 & $\begin{array}{l}\text { Abu } \\
\text { Arish }\end{array}$ & 197112 & $\begin{array}{l}8193 \\
1 \\
\end{array}$ & $\begin{array}{l}8214 \\
0 \\
\end{array}$ & $\begin{array}{l}16407 \\
1 \\
\end{array}$ & $\begin{array}{l}956 \\
4 \\
\end{array}$ & $\begin{array}{l}2347 \\
7 \\
\end{array}$ & $\begin{array}{l}3304 \\
1 \\
\end{array}$ & $12 / 19$ & $2 / 2$ & $12 / 7$ & $0 / 5$ & $0 / 2$ & $\begin{array}{l}26(12 . \\
4)\end{array}$ & $1: 7,581$ \\
\hline 4 & Samtah & 147330 & $\begin{array}{l}5784 \\
9\end{array}$ & $\begin{array}{l}5564 \\
6\end{array}$ & $\begin{array}{l}11349 \\
5\end{array}$ & $\begin{array}{l}133 \\
61\end{array}$ & $\begin{array}{l}2047 \\
4\end{array}$ & $\begin{array}{l}3383 \\
5\end{array}$ & $12 / 18$ & $1 / 1$ & $12 / 5$ & $0 / 1$ & $0 / 0$ & $18(8.6)$ & $1: 8,185$ \\
\hline 5 & Al Harth & 18586 & 3285 & $\begin{array}{l}1466 \\
8\end{array}$ & 17953 & 278 & 355 & 633 & $0 / 4$ & $1 / 1$ & $0 / 2$ & $0 / 0$ & $0 / 0$ & (1.0) & $1: 9,293$ \\
\hline 6 & Damad & 71601 & $\begin{array}{l}2810 \\
0\end{array}$ & $\begin{array}{l}2813 \\
8\end{array}$ & 56238 & $\begin{array}{l}595 \\
9 \\
\end{array}$ & 9404 & $\begin{array}{l}1536 \\
3\end{array}$ & $3 / 7$ & $1 / 1$ & $3 / 2$ & $0 / 0$ & $0 / 0$ & $5(2.4)$ & $\begin{array}{l}1: 14,32 \\
0\end{array}$ \\
\hline 7 & Ar Rayth & 18961 & 8420 & 9871 & 18291 & 123 & 547 & 670 & $2 / 4$ & $1 / 1$ & $3 / 1$ & $0 / 0$ & $0 / 0$ & $4(1.9)$ & $1: 4,740$ \\
\hline 8 & Baysh & 70421 & $\begin{array}{l}2811 \\
4 \\
\end{array}$ & $\begin{array}{l}2779 \\
2\end{array}$ & 55906 & $\begin{array}{l}491 \\
5\end{array}$ & 9600 & $\begin{array}{l}1451 \\
5 \\
\end{array}$ & $14 / 14$ & $1 / 1$ & $14 / 3$ & $0 / 1$ & $0 / 0$ & $18(8.6)$ & $1: 3,912$ \\
\hline 9 & Farasan & 17999 & 7682 & 8302 & 15984 & 556 & 1459 & 2015 & $3 / 3$ & $1 / 1$ & $3 / 4$ & $0 / 1$ & $0 / 0$ & $8(3.8)$ & $1: 2,249$ \\
\hline 10 & Ad Dair & 58494 & $\begin{array}{l}2631 \\
2\end{array}$ & $\begin{array}{l}2707 \\
3\end{array}$ & 53385 & $\begin{array}{l}126 \\
9\end{array}$ & 3840 & 5109 & $3 / 10$ & $1 / 1$ & $4 / 1$ & $0 / 0$ & $0 / 0$ & $5(2.4)$ & $\begin{array}{l}1: 11,69 \\
8\end{array}$ \\
\hline 11 & $\begin{array}{l}\text { Ahad } \mathrm{Al} \\
\text { Masariha } \\
\mathrm{h}\end{array}$ & 110710 & $\begin{array}{l}4756 \\
4\end{array}$ & $\begin{array}{l}4566 \\
9\end{array}$ & 93233 & $\begin{array}{l}600 \\
2\end{array}$ & $\begin{array}{l}1147 \\
5\end{array}$ & $\begin{array}{l}1747 \\
7\end{array}$ & $8 / 12$ & $1 / 1$ & $8 / 3$ & $0 / 0$ & $0 / 0$ & 11(5.3) & $\begin{array}{l}1: 10,06 \\
4\end{array}$ \\
\hline 12 & $\begin{array}{l}\text { Al } \\
\text { Aydabi }\end{array}$ & 31735 & $\begin{array}{l}4756 \\
4 \\
\end{array}$ & $\begin{array}{l}4566 \\
9 \\
\end{array}$ & 27419 & $\begin{array}{l}130 \\
5\end{array}$ & 3011 & 4316 & $2 / 4$ & $1 / 1$ & $3 / 2$ & $0 / 0$ & $0 / 0$ & $5(2.4)$ & $1: 6,347$ \\
\hline 13 & $\begin{array}{l}\text { Al } \\
\text { Aridah }\end{array}$ & 76705 & $\begin{array}{l}1319 \\
8\end{array}$ & $\begin{array}{l}1422 \\
1 \\
\end{array}$ & 66133 & $\begin{array}{l}409 \\
5\end{array}$ & 6477 & $\begin{array}{l}1057 \\
2 \\
\end{array}$ & $7 / 8$ & $1 / 1$ & $5 / 4$ & $0 / 0$ & $0 / 0$ & $9(4.3)$ & $1: 8,523$ \\
\hline 14 & Ad Darb & 69134 & $\begin{array}{l}3290 \\
0\end{array}$ & $\begin{array}{l}3323 \\
3 \\
\end{array}$ & 52733 & $\begin{array}{l}246 \\
3\end{array}$ & $\begin{array}{l}1393 \\
8\end{array}$ & $\begin{array}{l}1640 \\
1\end{array}$ & $4 / 4$ & $1 / 1$ & $3 / 2$ & $0 / 2$ & $0 / 0$ & $7(3.3)$ & $1: 9,876$ \\
\hline 15 & At Tuwal & 54326 & $\begin{array}{l}2544 \\
8 \\
\end{array}$ & $\begin{array}{l}2728 \\
5 \\
\end{array}$ & 48690 & $\begin{array}{l}211 \\
5 \\
\end{array}$ & 3521 & 5636 & $0 / 5$ & $2 / 2$ & $0 / 4$ & $0 / 0$ & $0 / 0$ & $4(1.9)$ & $\begin{array}{l}1: 13,58 \\
1\end{array}$ \\
\hline 16 & Harub & 29064 & $\begin{array}{l}2488 \\
2\end{array}$ & $\begin{array}{l}2380 \\
8\end{array}$ & 26675 & 803 & 1586 & 2389 & $3 / 5$ & $0 / 1$ & $3 / 0$ & $0 / 0$ & $0 / 0$ & $3(1.4)$ & $1: 9,688$ \\
\hline 17 & Fayfa & 29793 & $\begin{array}{l}1322 \\
8 \\
\end{array}$ & $\begin{array}{l}1344 \\
7 \\
\end{array}$ & 27096 & 850 & 1847 & 2697 & $1 / 3$ & $1 / 1$ & $0 / 1$ & $0 / 1$ & $0 / 0$ & $2(1.0)$ & $\begin{array}{l}1: 14,89 \\
6\end{array}$ \\
\hline Tot & & $\begin{array}{l}136511 \\
0\end{array}$ & $\begin{array}{l}5451 \\
97\end{array}$ & $\begin{array}{l}5598 \\
98\end{array}$ & $\begin{array}{l}11050 \\
95\end{array}$ & $\begin{array}{l}830 \\
25\end{array}$ & $\begin{array}{l}1769 \\
90\end{array}$ & $\begin{array}{l}2600 \\
15\end{array}$ & $\begin{array}{l}103 / 1 \\
52\end{array}$ & $21 / 22$ & $\begin{array}{l}104 / \\
52\end{array}$ & $0 / 25$ & $0 / 8$ & 189 & $1: 7,073$ \\
\hline
\end{tabular}

Abbreviations: PHCs, Primary Health Care Centers; S, Saudis; Non-S, non-Saudis; F, Female; M, Male; DC, Dental Clinic; T, Total

Based on the MOH statistical yearly book, there are 287 oral health providers, including 209 dentists, 76 dental assistants, and two dental hygienists who are working in $\mathrm{MOH}$ facilities in Jazan. 103 PHCs included 110 dental clinics in seven areas in the Jazan region (Table-2). Jazan City as central area has 13 PHCs with 15 oral providers, two of whom are study abroad. The highest number of dental clinics in the region is 25 PHCs located in the western area (including Sabya, Damad, and Harub). This area includes 23 dentists, two of whom study abroad. There are 21 hospitals that include dental components, which include 60 dental clinics that provide dental services (Table-3). Jazan City has a high number of hospital and dental clinics, with three and 20 respectively. Abu Arish has two hospitals with eight dental clinics. 
Mosa A. Shubayr et al; Saudi J Oral Dent Res, Jan, 2021; 6(1): 81-87

Table-2: Descriptive Statistics of MOH Primary Healthcare Centres (PHCs) in Jazan

\begin{tabular}{|c|c|c|c|c|c|c|c|c|c|}
\hline \multicolumn{2}{|c|}{ Governorate (Mohafadat) } & \multirow[t]{2}{*}{ Population } & \multicolumn{2}{|c|}{ Health Facility } & \multicolumn{4}{|c|}{$\begin{array}{l}\text { Providers (Dentists) } \\
\text { PHCs }\end{array}$} & \multirow{2}{*}{$\begin{array}{l}\text { Dentist- } \\
\text { Population } \\
\text { Ratio } \\
\end{array}$} \\
\hline Area & Cities & & $\begin{array}{l}\text { Clinic } \\
\text { Number }\end{array}$ & PHCs & Resident & Registrar & Consultant & $\begin{array}{l}\text { Study } \\
\text { Abroad }\end{array}$ & \\
\hline Centeral & Jazan & 134764 & 13 & 13 & 13 & 0 & 0 & 2 & $1: 8,984$ \\
\hline Northern & $\begin{array}{l}\text { Baish, Al Darb } \\
\text { Al Sheqiq, Harub }\end{array}$ & 168619 & 22 & 21 & 19 & 0 & 0 & 2 & $1: 8,029$ \\
\hline Southern & $\begin{array}{l}\text { Al Harth, Ahad Al } \\
\text { Masarihah, Samtah, } \\
\text { Atwal } \\
\text { Farasan }\end{array}$ & 348951 & 23 & 23 & 22 & 0 & 0 & 3 & $1: 13,958$ \\
\hline Eastern & Al Dair & 58494 & 3 & 3 & 3 & 0 & 0 & 0 & $1: 19,498$ \\
\hline Western & Sabya, Dama, Harub & 329040 & 25 & 21 & 21 & 0 & 0 & 2 & $1: 14,306$ \\
\hline Mountain & Fyfa, Al Aydabi & 61528 & 3 & 3 & 4 & 0 & 0 & 0 & $1: 15,382$ \\
\hline Meddile & Abu Arish, Aridah, & 273817 & 21 & 19 & 22 & 0 & 0 & 0 & $1: 12,446$ \\
\hline Total & & 1365110 & 110 & 103 & 104 & 0 & 0 & 9 & $1: 12,081$ \\
\hline
\end{tabular}

Abbreviations: PHCs, Primary Health Care Centers

Table-3: Descriptive Statistics of MOH Hospitals in Jazan

\begin{tabular}{|c|c|c|c|c|c|c|c|c|c|}
\hline \multirow[t]{2}{*}{$\#$} & \multirow{2}{*}{$\begin{array}{l}\text { Governorate } \\
\text { (Mohafadat) }\end{array}$} & \multirow[t]{2}{*}{ Population } & \multicolumn{2}{|c|}{ Health Facility } & \multicolumn{4}{|c|}{ Providers (Dentists) Hospital } & \multirow{2}{*}{$\begin{array}{l}\text { Dentist- } \\
\text { Population } \\
\text { Ratio } \\
\end{array}$} \\
\hline & & & $\begin{array}{l}\text { Clinic } \\
\text { Number }\end{array}$ & Hospitals & Resident & Registrar & Consultant & $\begin{array}{l}\text { Study } \\
\text { Abroad }\end{array}$ & \\
\hline 1 & Jazan & 134764 & 20 & 3 & 8 & 10 & 6 & 5 & $1: 4,647$ \\
\hline 2 & Sabya & 228375 & 4 & 1 & 3 & 4 & 0 & 0 & $1: 32,625$ \\
\hline 3 & Abu Arish & 197112 & 8 & 2 & 7 & 5 & 2 & 1 & $1: 13,140$ \\
\hline 4 & Samtah & 147330 & 3 & 1 & 5 & 1 & 0 & 0 & $1: 36,832$ \\
\hline 5 & Al Harth & 18586 & 1 & 1 & 2 & 0 & 0 & 0 & $1: 9,292$ \\
\hline 6 & Damad & 71601 & 1 & 1 & 2 & 0 & 0 & 0 & $1: 35,800$ \\
\hline 7 & Ar Rayth & 18961 & 1 & 1 & 1 & 0 & 0 & 1 & $1: 9,480$ \\
\hline 8 & Baysh & 70421 & 2 & 1 & 3 & 1 & 0 & 0 & $1: 17,605$ \\
\hline 9 & Farasan & 17999 & 6 & 1 & 4 & 1 & 0 & 0 & $1: 3,600$ \\
\hline 10 & Ad Dair & 58494 & 1 & 1 & 1 & 0 & 0 & 0 & $1: 58,494$ \\
\hline 11 & $\begin{array}{l}\text { Ahad Al } \\
\text { Masarihah }\end{array}$ & 110710 & 2 & 1 & 3 & 0 & 0 & 0 & $1: 36,903$ \\
\hline 12 & Al Aydabi & 31735 & 1 & 1 & 2 & 0 & 0 & 0 & $1: 15,867$ \\
\hline 13 & Al Aridah & 76705 & 2 & 1 & 4 & 0 & 0 & 0 & $1: 19,176$ \\
\hline 14 & Ad Darb & 69134 & 3 & 1 & 2 & 2 & 0 & 0 & $1: 17,283$ \\
\hline 15 & At Tuwal & 54326 & 3 & 2 & 4 & 0 & 0 & 0 & $1: 13,581$ \\
\hline 16 & Harub & 29064 & 0 & 0 & 0 & 0 & 0 & 0 & 0 \\
\hline 17 & Fayfa & 29793 & 2 & 1 & 1 & 1 & 0 & 0 & $1: 14,897$ \\
\hline \multicolumn{2}{|c|}{ Total } & 1365110 & 60 & 21 & 52 & 25 & 8 & 7 & $1: 14,838$ \\
\hline
\end{tabular}

Abbreviations: PHCs, Primary Healthcare Centers

Almost half, 104 (49.7\%) work in PHCs and $85(40.7 \%)$ work in hospitals in the region. Only 4 $(1.9 \%)$ as administrative and $16(7.7 \%)$ of the providers purse their graduate studies whether in the country or abroad (Table $1 \& 2$ ). Most $(76.6 \%)$ of the dentists are residents, eight are consultants, and 25 work as registrars. Most of oral providers in Jazan are male with 85 males and 12 females in PHCs. Of the 37 (17.7\%) dentists who work in Jazan city, most work in the government dental center in the city. These providers served 134,000 people, which represents one provider per 3,600 people. Since there are no dental clinics in Atwal and Al Harth, no dentists work in those areas. Abu Arish has 26 (12.4\%) dentists serving 197,000 people, which represents one provider per 7,000 individuals, followed by Sabya with 24 (11.5\%) dentists serving 228,000 individuals, which represents one provider per almost 10,000 people.

This study focused on Jazan region, one of the thirteen regions of the Kingdom of Saudi Arabia. Jazan region (also spelled Jizan, Gizan, or Gazan) situated on the coast of the Red Sea, in the southwest corner of Saudi Arabia. The population is mostly Saudi nationals with some expatriates [22]. Jazan region has a population of approximately 1.6 million people, with Saudi nationals making up 1.2 million [23]. Approximately $54.2 \%$ are male and $45.8 \%$ are female. Most of the region's residents live in the major cities like Sabya, Jazan, and Abu Arish with 228,000, 197,000, and 134,000 residents respectively [24]. 
Mosa A. Shubayr et al; Saudi J Oral Dent Res, Jan, 2021; 6(1): 81-87

PHC provide preventive services and basic dental treatments such as simple composite and amalgam fillings, oral hygiene, scaling and root planning. With regards to general hospitals, there are 21 hospitals which provide specialized services such as Maxillofacial surgery, Endodontics, and complex treatments that are not available from governmental PHCs. These services were provided through 60 dental clinics. Thus patients needing more specialized treatment will be refereed to specialized dental clinics as discussed above that have long waiting lists. This can create barriers to care service utilization and the overall quality of healthcare.

There are 209 dentists in Jazan region, which represents a ratio of one $\mathrm{MOH}$-affiliated dentist to almost 6600 people. This result is higher than the $\mathrm{MOH}$ provider-population ratio in Riyadh, Jeddah and the Eastern region, which was (1: 9,700), (1: 12,600), and (1: 8700) respectively. This shortage in oral health providers indicates that many people in the region might not receive preventive and basic dental treatment and advanced treatments, or that there were difficulties accessing these services.

Moreover, this study found that a high percentage, $17.7 \%$ of the providers work in Jazan City. These practitioners provide service to more than 134,000 people, which represent a dentist-population ratio of 1:3600. Some areas such as Sabya, Al Darb, Atwal, Aldayer, Harub, and Fyfa have few practitioners providing dental service compared to larger populations, which indicates that one provider serves more than 10,000 people. Many cities in Jazan such as Al Harth and Atwal do not have dental service at all. The residents in these cities must travel to PHCs and hospitals to receive the service, thereby increasing the workload at some $\mathrm{MOH}$ facilities, which leads to lower accessibility and quality of service. Despite the high number of providers, there is a need for a better dental workforce distribution that provide preventive and basic dental treatment. It has been reported that the physical location of the dental clinic is the most important factor influencing utilization of dental services [26]. Indeed, transportation difficulties are a commonly reported barrier to dental care access [27]. There is an unequal distribution of dental workforce even at the country level since over $80 \%$ of the dentists in the KSA were working in the cities of Riyadh or Makah, or the Eastern province [6]. A recently published research study of the distribution of dental clinics, private and public) within s Saudi Arabia metropolitan area (Al Medina) found that the majority of the clinics were located within $3 \mathrm{~km}$ form the city centre compromising physical access to dental healthcare [28].

Based on the descriptive results of the study's variables, the majority $(76.6 \%)$ of the providers work as residents in PHCs, which indicate that most of providers in PHCs have a Bachelor degree in dentistry and are only able to provide only basic dental treatment to the people of Jazan region. Also, this high number of providers in PHCs might be due to the few positions available in postgraduate programs in the country, or due to a lack of support from their organizations to pursue their studies. In addition, there are only two dental hygienists who are considered as the first line of dental prevention. Some studies found that dental hygienists are more likely to offer dental preventive services in their work than other dental providers [29]. This indicates that preventive activities in the region are very low. There are only eight dental public health (DPH) practitioners, which also helps to explain why preventive activities are very low in the region. DPH practitioners are more likely to practice preventive care than other oral providers [29]. The most recently published data about the specialties of dentists in Jazan region 2017, included information about dentists' specialties working both in private and public sector in the region [30]. This study found that the majority of region's practicing dental professionals are general practitioners, which means that they had a bachelor's degree followed by prosthodontics and maxillo-facial surgeon [30].

It is noteworthy that only $22 \%$ of the dentists in the Kingdom are actually Saudis, with the rest being foreign nationals. These statistics demonstrate that the KSA faces challenges in developing a Saudis oral healthcare workforce able to meet the country's general and specialized dental needs. Currently Saudi dental schools graduate more than 1000 graduates per year [30]. There are seven dental schools in Riyadh, five in Makkah, three in Al Qasseem, and two in the Eastern province. The low number of dental health professionals in Jazan could be due to the paucity of dental schools in the region, with only one dental school for the region. In 2018, there were about 99 students 46 males and 53 females who graduated from the College of Dentistry in Jazan. This number was the fourth highest number of dentists graduating among Saudi dental schools [31]. Approximately 83 dentists were enrolled in postgraduate programs in 2018; about 64 were enrolled inside the KSA, $47(56.0 \%)$ of whom were male and $17(20.2 \%)$ of whom were female. In addition, 19 (16 male and 3 female) (19.0\%) dentists studied abroad. There are approximately 100 male and female dental graduates every year in Jazan [31]. This number is considered the fourth highest number of dentists graduating among Saudi dental schools. The large number of graduates makes it hard to find a job, especially in the public sector, where most of the graduates prefer to work due to long-term security and postgraduate education opportunities. However, the MOH plans to spend over 23 billion Saudi riyals on a new initiative to meet the government's 2030 Vision [32]. The study opens a window into the government's plans to address this issue. 
Mosa A. Shubayr et al; Saudi J Oral Dent Res, Jan, 2021; 6(1): 81-87

This study was the first effort to describe the public dental health services in the Jazan region of the KSA with respect to the dental healthcare facilities, oral health providers and population characteristics. However, there are several limitations that should be considered when utilizing the results of this study. First, there is a lack of data regarding oral health service and oral providers in the Jazan region. Documents used in this study provided information on the number of dental services, distribution per type of services delivered and number of active $\mathrm{MOH}$ affiliated dentists and dental allied professionals. However, it did not provide adequate information on the type of service offered, accessibility to dental services and characteristics of dental providers such as type of specialty. The study is also limited due to the fact that it only considered dental services based on the collected documents, but the system in reality has been changing so rapidly that previous documents might not reflect the most recent developments.

\section{CONCLUSIONS}

There are numerous issues in encountering dental service in the Jazan region, such as the distribution of providers and services, which point to why the region experiences lower accessibility and quality of dental treatment. The low number of dental hygienists and assistants might be one of reasons that there are a low number of preventive activities in the region. Lastly, the type of facility (PHCs or hospitals) is important in considering distribution, since each facility has a different function within the system. Further primary research focusing on different cities or geographical areas in the Jazan region is needed to validate these findings.

\section{Ethical Statement}

Only openly accessible, non-identifiable data and information was used for this research, and therefore ethics approval was not necessary.

Declaration of Competing Interest: The author declared that there is no conflict of interest.

\section{ACKNOWLEDGMENTS}

Authors would like to acknowledge Jazan University which has supported this study at the University of Western Australia. This support is highly acknowledged and appreciated. The authors would also like to extend their sincere gratitude to the school authorities at the University of western Australia for their continuous support throughout the paper.

Funding: The study conducted with no financial support.

\section{REFERENCES}

1. Shaker, R. E., Babgi, A. A. (2009). Women in dentistry: A perspective on major universities in
Saudi Arabia. Part 1: Historical background. The Saudi Dental Journal, 21 (3), 103-106. https://doi.org/10.1016/j.sdentj.2009.03.001

2. Almalki, M., Fitzgerald, G., \& Clark, M. (2011). Health care system in Saudi Arabia: an overview. Eastern Mediterranean Health Journal, 17(10), 784-793. https://doi.org/10.26719/2011.17.10.784

3. Alshahrani, A., \& Raheel, S. (2016). Health-care System and Accessibility of Dental Services in Kingdom of Saudi Arabia: An Update. Journal of International Oral Health, 8, 883-887. https://doi.org/10.2047/jioh-08-08-10

4. Al Yousuf, M., Akerele, T.M., \& Al Mazrou, Y.Y. (2002). Organization of the Saudi health system. Eastern Mediterranean Health Journal, 8 ((5-4, ..653-645

https://apps.who.int/iris/handle/10665/119213

5. Jannadi, B., Alshammari, H., Khan, A. \& Hussain, R. (2008). Current structure and future challenges for the healthcare system in Saudi Arabia. Asia Pacific Journal of Health Management, 3 (1), 43. https://search.informit.com.au/documentSummary ;dn=426956885024415;res=IELHEA

6. Saudi Ministry of Health. Health Statistical Year Book; Ministry of Health: Riyadh, 2019 https://www.moh.gov.sa/en/Ministry/Statistics/bo ok/Pages/default.aspx

7. Albejaidi, F. M. (2010). Healthcare system in Saudi Arabia: An analysis of structure, total quality management and future challenges. Journal of Alternative Perspectives in the Social Sciences, 2 (2), 794-818.

http://www.japss.org/upload/16.Fahd[1].pdf

8. World Health Organization. (2000). The world health report 2000: health systems: improving performance. World Health Organization. https://www.who.int/whr/2000/en/

9. Bakhsh, A., Garot, M.A., Kaawach, W., Al-Jafari, Y.A.R, Al-Shamlan, O.A.S., Otaibi, K.A., \& AbuAbah, A.M. (2017, n.d). Health For All. The Business Year. https://www.thebusinessyear.com/saudi-arabia2017/many-aspects/column

10. Al-Hanawi, M. K., Khan, S. A., \& Al-Borie, H. M. (2019). Healthcare human resource development in Saudi Arabia: Emerging challenges and opportunities - A critical review. Public Health Reviews, 40, 1. https://doi.org/10.1186/s40985019-0112-4

11. Saudi Ministry of Health. Patient experience measurement program. 2020.

https://www.moh.gov.sa/en/Ministry/pxmp/Docu ments/MoH-PXMP-Q3-2020-(v5.0).pdf.

12. Gosadi, I. M. (2020). Case report of patient experience influenced by inadequate interactions between primary, secondary, and tertiary healthcare services in the south of Saudi Arabia. Clinical Case Reports, 8(2), 299-304. https://doi.org/10.1002/ccr3.2617 
Mosa A. Shubayr et al; Saudi J Oral Dent Res, Jan, 2021; 6(1): 81-87

13. Al-Malik, M. I., \& Rehbini, Y. A. (2006). Prevalence of dental caries, severity, and pattern in age 6 to 7-year-old children in a selected community in Saudi Arabia. Journal of Contemporary Dental Practice, 7(2), 46-54. https://doi.org/10.5005/jcdp-7-2-46

14. Al Shammery, A. R., Guile, E. E., \& EI Backly, M. (1990). Prevalence of caries in primary school children in Saudi Arabia. Community Dentistry and Oral Epidemiology, 18(6), 320-321. https://doi.org/10.1111/j.16000528.1990.tb00089.x

15. Alhabdan, Y. A., Albeshr, A. G., Yenugadhati, N., \& Jradi, H. (2018). Prevalence of dental caries and associated factors among primary school children: A population-based cross-sectional study in Riyadh, Saudi Arabia. Environmental Health and Preventive Medicine, 23(1), 60. https://doi.org/10.1186/s12199-018-0750-Z

16. Farooqi, F. A., Khabeer, A., Moheet, I. A., Khan, S. Q., Farooq, I., \& Arrejaie, A. S. (2015). Prevalence of dental caries in primary and permanent teeth and its relation with tooth brushing habits among schoolchildren in Eastern Saudi Arabia. Saudi Medical Journal, 36(6), 737742. https://doi.org/10.15537/smj.2015.6.10888

17. Al-Ansari, A. (2014). Prevalence, severity, and secular trends of dental caries among various Saudi populations: A literature review. Saudi Journal of Medicine and Medical Sciences, 2(3), 142. https://doi.org/10.4103/1658-631x.142496

18. Saudi Minstery of Health. (n.d.) Dental Caries; facts and guidelines. Retrieved on December 2020 form

https://www.moh.gov.sa/en/HealthAwareness/Edu cationalContent/Diseases/DiseasesOralanddental/P ages/DentalCaries.aspx

19. Al Agili, D. E. (2013, January). A systematic review of population-based dental caries studies among children in Saudi Arabia. Saudi Dental Journal, 25(1),3-11.

https://doi.org/10.1016/j.sdentj.2012.10.002

20. Zailai, A., Quadri, M., \& Nayeem, M. (2014). Caries status of school children in Jazan city, KSA and its relation with dental literacy of their parents. Journal of Oral Health Research 5(1), 1-7.

21. Dosari, A. M. Al, \& Abdellatif, H. (2000). Oral health status of primary dentition among 551 children aged 6 to 8 years in Jazan, Saudi Arabia. Saudi Dental Journal, 12(2), 67-71.

22. Quadri, F. A., Hendriyani, H., Pramono, A., \& Jafer, M. (2015). Knowledge, attitudes and practices of sweet food and beverage consumption and its association with dental caries among schoolchildren in Jazan, Saudi Arabia. Eastern Mediterranean Health Journal, 21(6), 403-411. https://doi.org/10.26719/2015.21.6.403

23. General Authority of Statistics (2019). Population in Jazan region by gender, age group, and nationality. https://www.stats.gov.sa/en/6140

24. General Authority for Statistics, Population by Age Groups and Gender 2019. https://www.stats.gov.sa/en/43

25. General Authority for Statistics, Detailed results of JAZAN (general population and housing census 2010). https://www.stats.gov.sa/en/1393

26. Al-Hussyeen, A. J. A. (2010). Factors affecting utilization of dental health services and satisfaction among adolescent females in Riyadh City. Saudi Dental Journal, 22(1), 19-25. https://doi.org/10.1016/j.sdentj.2009.12.004.

27. M Orfali, D. S., \& S Aldossary, D. M. (2020). Utilization of Dental Services in Saudi Arabia: A Review of the Associated Factors. Saudi Journal of Oral and Dental Research, 05(03), 147-149. https://doi.org/10.36348/sjodr.2020.v05i03.002

28. Alsharif, A. T. (2020). Georeferencing of Current Dental Service Locations to Population Census Data: Identification of Underserved Areas in Al Madina, Saudi Arabia. SAGE Open, 10(4), 215824402098297.

https://doi.org/10.1177/2158244020982970

29. Shubayr, M. A., Alexander, L. R., Tabatabai, M. A., \& Alagili, D. E. (2019). Knowledge, attitude and practice of oral health promotion among oral health providers in Kingdom of Saudi Arabia. Journal of Contemporary Dental Practice, 20(2), 231-238. https://doi.org/10.5005/jp-journals10024-2503

30. AlBaker, A. A., Al-Ruthia, Y. S. H., AlShehri, M., \& Alshuwairikh, S. (2017). The characteristics and distribution of dentist workforce in Saudi Arabia: A descriptive cross-sectional study. Saudi Pharmaceutical Journal, 25(8), 1208-1216. https://doi.org/10.1016/j.jsps.2017.09.005

31. Ministry of Education, Higher Education, Number-of-graduates-by-the-field-of-study-2013-

2018. https://data.gov.sa/Data/ar/dataset/field-ofstudy-2013-2018

32. Saudi Government. (2016) National Transformation Program 2020. https://www.vision2030.gov.sa/en/programs/NTP 